\title{
The application of a Fish Assemblage Integrity Index (FAll) in a Southern African river system
}

\author{
Wilbert T Kadye* \\ Department of Biological Sciences, TREP Trust, University of Zimbabwe, PO Box MP 167, Mt Pleasant, Harare, Zimbabwe
}

\begin{abstract}
The Fish Assemblage Integrity Index (FAII) was used to determine the status of the fish assemblage in relation to humaninduced factors in 3 segments of the Nyagui River, Zimbabwe. The $1^{\text {st }}$ and upstream segment, with a relative score of 56.5\%, was classified as largely modified. The presence of exotic predators, Micropterus salmoides, that constituted $>10 \%$ of the fish population sample, was linked to this low score in this segment that had low habitat diversity. The $2^{\text {nd }}$ and middle segment had a relative score of $91.6 \%$ and was classified as unmodified. Species that are intolerant to habitat modification, which included Opsaridium zambezense, Chiloglanis neumanni and Zaireichthys rotundiceps, were collected. Habitat diversity increased while the proportional abundance of $M$. salmoides decreased in this segment. The $3^{\text {rd }}$ and downstream segment, with a score of $81.5 \%$, was classified as largely natural. This score was mainly obscured by rare and migratory species that were expected at low altitude but were not collected. Nevertheless, intolerant species were collected from this segment. Habitat diversity was highest while the proportional abundance of largemouth bass, Micropterus salmoides, was lowest. It is recommended that more studies be carried out to test the consistency of the FAII in determining the impact of introduced species on native species, and to test the impact of other human activities on fish communities in Zimbabwean rivers.
\end{abstract}

Keywords: biomonitoring, fish assemblage integrity index, river segments, habitat diversity, exotic species

\section{Introduction}

As rivers continue to be degraded worldwide, the use of biotic indices to assess their ecosystem integrity has increased (Ganasan and Hughes, 1998). This is because many countries, particularly the poorer ones, find it difficult to consistently monitor their aquatic systems using physical and chemical variables because of a lack of funds (Bozzetti and Schulz, 2004). Since fish are an integral component of aquatic ecosystems, they are now being widely used in biomonitoring exercises. Fishes, especially in rivers, are increasingly threatened by human activities that place a heavy demand on freshwater resources, and freshwater fishes are ranked as the most threatened group of vertebrates (Collares-Perreira and Cowx, 2004). In Southern Africa, at least 24 species are considered to be rare or endangered (Skelton, 1990) and in Zimbabwe one species that prefers flowing water may now be extinct (Marshall and Gratwicke, 1999). The only published account of Zimbabwean stream fishes, a survey of the upper Manyame catchment, showed that river regulation, pollution and exotic predators on fish reduce the abundance and distribution of native species (Gratwicke et al., 2003).

Karr (1981) pioneered the use of fish for biomonitoring of streams and rivers when he developed the Index of Biotic Integrity (IBI). A typical IBI would include a series of metrics, based on assemblage structure and function, to calculate an index score that is compared with a score expected under largely natural conditions (Oberdorff et al., 2001). The metrics, therefore, attempts to describe the changes that occur in fish assemblages as the river system becomes modified. The IBI has gained popularity over the last 20 years and has been used in temperate regions

\footnotetext{
* To whom all correspondence should be addressed.

祍 +263 (0)4 303211; fax: +263 (0)4 333334;

e-mail: kadyew@yahoo.com

Received 10 July 2007; accepted in revised form 20 November2007.
}

(North America (for example, Osborne et al., 1992), Europe (see Billiard et al., 1999; Belpaire et al., 2000; Oberdorff et al., 2001; Briene et al., 2004), and New Zealand (Joy and Death, 2004)), and tropical and subtropical regions (India (Ganasan and Hughes, 1998), Brazil (Bozzetti and Schulz, 2004), Guinea (Hugueny et al., 1996) and Cameroon (Toham and Teugels, 1999)), to examine, inter alia, impacts of deforestation and other anthropogenic disturbances on fish in rivers.

In Southern Africa, one of the first attempts to use fish in biomonitoring was in the Okavango River (Namibia) (Hocutt et al., 1994). It was concluded that it was difficult to use fish for biomonitoring purposes because of the scarcity of fish community data. It was against this background that Kleynhans (1999) developed the Fish Assemblage Integrity Index (FAII) for application in South African rivers. Most biotic indices have been used to assess rivers that are affected by pollution, but few studies have considered the impact of other factors such as the impact of exotic species, which is a threat to fish in many Zimbabwean rivers (Minshull, 1993).

The aim of this study was to determine whether the FAII could be applied to the Nyagui River, and whether it would reveal the effect of the introduction of exotic species. The Nyagui River is part of the lower Zambezi ichthyological region where about 50 species have been collected in the Zimbabwean portion (Bell-Cross and Minshull, 1988). Based on a review of the available literature, this is the first attempt to use the FAII in a Zimbabwean river.

\section{Materials and methods}

\section{Study area}

The Nyagui River is a major tributary of the Mazowe River, which drains north-eastern Zimbabwe (Fig. 1). The river, which is part of the lower Zambezi system, has a catchment area of about $825 \mathrm{~km}^{2}$. The mean annual rainfall is relatively high (850 




Figure 1

Segments and sampling stations on the Nyagui River and its tributaries, as well as its confluence with the Mazowe River

mm at Marondera (DWD, 2002)). It is highly seasonal and the rivers flow strongly during the rainy season (November-April), diminishing during the course of the dry season to reach their lowest levels in October-November. By this time, the upstream sections and most of the smaller tributaries have ceased to flow although the Nyagui River itself is perennial.

The main land use activity for the catchment is communal farming. The river and its tributaries were divided into 3 segments based on the dominant substrate type. The upper segment, at altitudes exceeding $1400 \mathrm{~m}$ a.m.s.l. (sampling Stations 1 to 5), flows through extensive areas of grassland and wetlands. This section typically consists of pools with sandy bottoms and grassy verges with extensive macrophyte growth (commonly Phragmites and Nymphaea spp.). The mean discharge during the sampling period, determined at each station by multiplying the velocity and the area of the stream cross-section, was $1.92 \mathrm{~m}^{3} \cdot \mathrm{s}^{-1}$. The middle segment (sampling Stations 6 to 12) ranges in altitude from 1000 to $1400 \mathrm{~m}$ a.m.s.l. where the river flows through largely degraded Brachystegia-Julbernadia woodland and its bed is rocky with occasional sandbanks. The mean discharge was $3.0 \mathrm{~m}^{3} \cdot \mathrm{s}^{-1}$.The lower segment (sampling Stations 13 and 14) is below $1000 \mathrm{~m}$ a.m.s.l. and the river bed is typically rocky. In this section some sand banks and alluvial terraces are covered with Phragmites. The mean daily discharge was $4.9 \mathrm{~m}^{3} \cdot \mathrm{s}^{-1}$.

\section{Data sampling}

Stations 1 to 13 were sampled in October 2004 (before the rains), November 2004 (after the first rains) and in January 2005 when the river was flowing strongly. Station 14 on the Mazowe River, added during the course of the sampling, was sampled only in November 2005 and January 2005. A Smith-Root VI-A electrofisher (Smith-Root Inc., Vancouver, WA, USA) powered by a Honda EZ4500 220V generator was used to sample fish in the different segments of the river. All the fish caught were identified to species level using Bell-Cross and Minshull (1988) and Skelton (2001) and counted.

\section{Data analysis}

An indirect gradient analysis method, Detrended Gradient Analysis (DCA) was first used to explore the distribution pattern of the species among the sites in the three segments. Ordination was done using CANOCO version 4 (Ter Braak and Smilauer, 1998). All fish species sampled were then categorised according to an intolerance index (IT), frequency of occurrence (per segment) and health rating (per segment). The IT took into account trophic preference and specialisation, habitat preference and specialisation, requirements for flowing water during different life stages and association with habitats with unmodified water quality (Kleynhans, 1999). Each species was scored for low preference and specialisation (rating $=1$ ), moderate preference and specialisation (rating = 3) and high preference and specialisation (rating $=5$ ). The mean of the ratings were calculated to obtain an intolerance score ranging from 1 (tolerant species) to 5 (intolerant species). The work of Bell-Cross and Minshull (1988), Skelton (2001), Gratwicke et al. (2003) and Kadye and Marshall (2007) was used in estimating the intolerance ratings. Frequency of occurrence (F) was calculated as the number of sampling stations in a segment at which a species was recorded divided by the total number of sampling stations in that segment. The metric was scored according to the uneven integers following Kleynhans (1999). A frequency of occurrence $<34 \%$ was considered infrequent and given a score of 1 , while 34 to $67 \%$ was assigned a score of 3 , and 67 to $100 \%$ was considered to be a widespread species and was assigned a score of 5 .

The health rating $(\mathrm{H})$ was the percentage of fish with evident disease, parasite load or other anomalies and a frequency of affected fish $>5 \%$ was given a score of $1,2-5 \%$ given a score of 3 and $<2 \%$ a score of 5 .

Observed and expected FAII values were calculated for each segment based on Kleynhans (1999), according to Eq. (1):

$$
\text { FAII }=\sum I T \times((F+H) / 2)
$$

where:

$$
\begin{aligned}
& I T=\text { intolerance rating } \\
& F=\text { frequency of occurrence } \\
& H=\text { health rating for each species in a segment }
\end{aligned}
$$

Expected values were based on a reference condition. The reference condition was based the work of Bell-Cross and Minshull (1988), Skelton 2001) and Kadye and Marshall (2007).

The relative FAII score (\%) was calculated based on Eq. (2):

$$
\text { Relative FAII }=\frac{\text { FAll }(\text { obs })}{\text { FAll }(\exp )} \times 100
$$

The interpretation of the FAII scores, based on Kleynhans (1999), is shown in Table 1.

The relative FAII scores in this study were based on the combined samples of the three sampling months since Hocutt et al. (1994) cautioned against the use of single samples in systems where the history of ichthyofauna under study is poorly known. In addition, the scores of many biotic indices have 


\begin{tabular}{|c|c|c|}
\hline \multicolumn{3}{|c|}{$\begin{array}{c}\text { TABLE 1 } \\
\text { The interpretation of the FAll according to the } \\
\text { categories set out in Kleynhans (1999) }\end{array}$} \\
\hline $\begin{array}{l}\text { Class } \\
\text { rating }\end{array}$ & $\begin{array}{l}\text { Expected conditions for integrity } \\
\text { classes }\end{array}$ & $\begin{array}{l}\text { Rela- } \\
\text { tive FAll } \\
\text { score } \\
\text { (\% of } \\
\text { expected) }\end{array}$ \\
\hline$A$ & $\begin{array}{l}\text { Unmodified, or approximately natural } \\
\text { conditions }\end{array}$ & 90-100 \\
\hline B & $\begin{array}{l}\text { Largely natural with few modifications. } \\
\text { Species richness and presence of intolerant } \\
\text { species indicate little modifications. }\end{array}$ & 80-89 \\
\hline $\mathrm{C}$ & $\begin{array}{l}\text { Moderately modified. A lower than expected } \\
\text { species richness and presence of most intol- } \\
\text { erant species. Health impairment may be } \\
\text { evident at the lower limit of this class. }\end{array}$ & \begin{tabular}{|c|}
$60-79$ \\
\end{tabular} \\
\hline $\mathrm{D}$ & $\begin{array}{l}\text { Largely modified. A lower than expected } \\
\text { species richness and absence or much } \\
\text { lowered presence of intolerant species } \\
\text { and moderately intolerant species. Health } \\
\text { impairment may become more evident at } \\
\text { the lower limit of this class. }\end{array}$ & 40-59 \\
\hline$E$ & $\begin{array}{l}\text { Seriously modified. A very lower than } \\
\text { expected species richness and general } \\
\text { absence of intolerant species and moder- } \\
\text { ately intolerant species. Health impairment } \\
\text { may become evident. }\end{array}$ & 20-39 \\
\hline $\mathrm{F}$ & $\begin{array}{l}\text { Critically modified. Extremely lowered } \\
\text { species richness and an absence of intoler- } \\
\text { ant and moderately tolerant species. Only } \\
\text { tolerant species may be present. Health } \\
\text { impairment is evident. }\end{array}$ & $0-19$ \\
\hline
\end{tabular}

been found to be unaffected by changes in seasons and flow (Karr, 1981).

Variables that were considered important in determining the FAII scores were the proportional abundance of largemouth bass, Micropterus salmoides, and habitat diversity. Bass is an exotic predator that is known to reduce the abundance and richness of local species (Gratwicke and Marshall, 2001). Habitat data were collected using methods described by Gorman and Karr (1978) and Schlosser (1982). Twenty transects were set up at each station at $5 \mathrm{~m}$ intervals perpendicular to the stream flow. Starting from the wetted edge, water column depth and average velocity (measured with an FP201 electronic current meter) were determined at $50 \mathrm{~cm}$ intervals along each transect and the dominant substrate was visually characterised within a radius of $25 \mathrm{~cm}$. The number of points assessed varied from 38 at the upper stations, where the streams were smaller, to 320 at the lower stations where the streams were larger. Each habitat was classified following Schlosser (1982) which identifies 4 depth classes, 5 velocity classes and 5 substrate classes, plus 2 other substrate classes (vegetation and debris). Each point could then be allocated to one of the potential 170 categories based on a combination of depth, velocity and substrate, e.g. 'shallow, slow, gravel' (Table 2). The proportion (\%) of each class at each station was determined. The proportion of each category was determined and a habitat diversity index was calculated using the Shannon diversity index (Eq. (3):

$$
H^{\prime}=-\sum p_{i} \ln p_{i}
$$

where:

$p_{i}$ is the proportion of category $i$ in the sample.

\begin{tabular}{|c|c|c|c|c|c|c|c|c|c|c|c|c|c|c|}
\hline \multicolumn{15}{|c|}{$\begin{array}{c}\text { TABLE } 2 \\
\text { The proportion (\%) of each habit }\end{array}$} \\
\hline & \multicolumn{14}{|c|}{ Stations } \\
\hline & 1 & 2 & 3 & 4 & 5 & 6 & 7 & 8 & 9 & 10 & 11 & 12 & 13 & 14 \\
\hline sl,vsh,vslo & 25 & 10 & 20 & 0 & 20 & 0 & 0 & 10 & 0 & 0 & 0 & 0 & 0 & 0 \\
\hline sl,sh,vslo & 25 & 10 & 30 & 0 & 30 & 0 & 5 & 0 & 0 & 0 & 0 & 0 & 0 & 0 \\
\hline sn,md,slo & 10 & 10 & 20 & 0 & 20 & 0 & 0 & 20 & 0 & 0 & 0 & 0 & 0 & 0 \\
\hline aqv & 35 & 0 & 30 & 5 & 30 & 10 & 10 & 10 & 5 & 5 & 10 & 5 & 5 & 5 \\
\hline rv & 5 & 0 & 0 & 5 & 0 & 0 & 5 & 10 & 0 & 0 & 0 & 0 & 5 & 0 \\
\hline sn,md,mf & 0 & 30 & 0 & 0 & 0 & 0 & 0 & 0 & 0 & 0 & 0 & 0 & 0 & 0 \\
\hline sn,dp,slo & 0 & 40 & 0 & 0 & 0 & 10 & 10 & 30 & 0 & 10 & 20 & 30 & 10 & 15 \\
\hline gr,sh,slo & 0 & 0 & 0 & 20 & 0 & 0 & 0 & 0 & 0 & 0 & 0 & 0 & 0 & 0 \\
\hline pb,dp,slo & 0 & 0 & 0 & 30 & 0 & 0 & 0 & 0 & 0 & 0 & 30 & 0 & 0 & 0 \\
\hline rk,dp,sl & 0 & 0 & 0 & 40 & 0 & 0 & 15 & 0 & 0 & 10 & 30 & 20 & 10 & 10 \\
\hline sl,sh,slo & 0 & 0 & 0 & 0 & 0 & 10 & 0 & 0 & 0 & 10 & 0 & 0 & 0 & 0 \\
\hline gr,sh,fs & 0 & 0 & 0 & 0 & 0 & 20 & 15 & 10 & 20 & 15 & 0 & 15 & 15 & 15 \\
\hline pb,md,fs & 0 & 0 & 0 & 0 & 0 & 25 & 25 & 0 & 30 & 20 & 0 & 0 & 30 & 20 \\
\hline pb,md,tr & 0 & 0 & 0 & 0 & 0 & 25 & 15 & 0 & 20 & 10 & 0 & 0 & 10 & 10 \\
\hline sn,sh,vslo & 0 & 0 & 0 & 0 & 0 & 0 & 0 & 10 & 0 & 0 & 5 & 0 & 0 & 0 \\
\hline sn,sh,slo & 0 & 0 & 0 & 0 & 0 & 0 & 0 & 0 & 15 & 10 & 0 & 0 & 5 & 5 \\
\hline pb,dp,fs & 0 & 0 & 0 & 0 & 0 & 0 & 0 & 0 & 10 & 10 & 0 & 0 & 10 & 10 \\
\hline sl,dp,vslo & 0 & 0 & 0 & 0 & 0 & 0 & 0 & 0 & 0 & 0 & 5 & 15 & 0 & 10 \\
\hline sn,dp,fs & 0 & 0 & 0 & 0 & 0 & 0 & 0 & 0 & 0 & 0 & 0 & 5 & 0 & 0 \\
\hline gr,sh,tr & 0 & 0 & 0 & 0 & 0 & 0 & 0 & 0 & 0 & 0 & 0 & 10 & 0 & 0 \\
\hline $\begin{array}{l}\text { Habitat } \\
\text { Diversity } \\
\text { index }\end{array}$ & 1.44 & 1.41 & 1.36 & 1.35 & 1.36 & 1.71 & 1.96 & 1.83 & 1.67 & 2.14 & 1.57 & 1.78 & 2.02 & 2.11 \\
\hline
\end{tabular}

Substrate categories: silt(sl), sand(sn), gravel(gr), pebble(pb) and rock (rk); depth categories: very shallow(vsh), shallow(sh), moderate(md), $\operatorname{deep}(d p)$; flow categories: very slow(vslo), slow(slo), moderate( $m f)$, fast(fs) and torrent(tr). Aquatic vegetation (aqv) and riparian vegetation (rv) were additional habitat types. 


\begin{tabular}{|l|c|c|c|c|}
\hline \multicolumn{5}{|c|}{ TABLE 3 } \\
DCA summary statistics for the species data \\
\hline & Axis 1 & Axis 2 & Axis 3 & Axis 4 \\
\hline Eigenvalue & 0.52 & 0.13 & 0.04 & 0.02 \\
\hline Length of axis & 3.35 & 1.43 & 1.39 & 1.24 \\
\hline $\begin{array}{l}\text { Cumulative \% variance } \\
\text { of species data }\end{array}$ & 32.70 & 40.80 & 43.40 & 44.60 \\
\hline
\end{tabular}

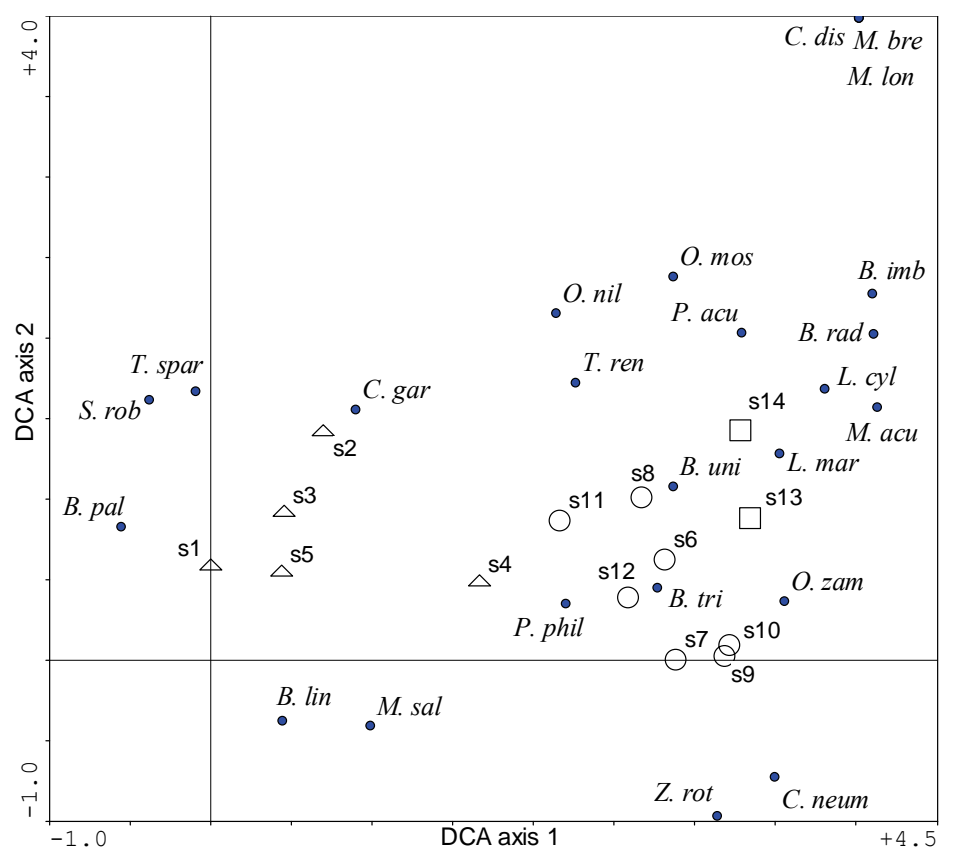

Figure 2

DCA ordination plot for species ( $\bullet$ and sampling stations of Segment $1(\triangle)$, Segment $2(0)$ and Segment $3(\square)$. The abbreviations are as follows: $\mathrm{C}$. dis = Cyphomyrus discorhynchus, M. Ion = Mormyrus longirostris, $M$. bre = Mesobola brevianalis, O. zam = Opsaridium zambezense, $B$. lin = Barbus lineomaculatus, $B$. rad $=B$. radiatus, $B$. tri $=$. trimaculatus, $B$. un $i=$ B. unitaeniatus, $L$. mar $=$ Labeobarbus marequensis, $L$. cyl $=$ Labeo cylindricus, B. imb = Brycinus imberi, M. acu $=$ Micralestes acutidens, Z. rot = Zaireichthys rotundiceps, C. gar = Clarias gariepinus, $C$. neum = Chiloglanis neumanni, $M$. sal $=$ Micropterus salmoides, $P$. phil $=$ Pseudocrenilabrus philander, $P$. acu $=$ Pharyngochromis acuticeps, $T$. spar = Tilapia sparmanii, $T$. ren $=$ T. rendalli, O. mos $=$ Oreochromis mossambicus, O. nil = O. niloticus and S. rob = Serranochromis robustus.

\section{Results}

DCA produced four axes that explained $44.6 \%$ of the total variance in the species data (Table 3). The first axis had a gradient of 3.35 units, indicating a full turnover in the assemblage among all stations along this axis. The sampling stations for the 3 segments were separated along the $1^{\text {st }}$ ordination axis (Fig. 2). Six species, namely Barbus paludinosus, B. lineomaculatus, Serranochromis robustus, Tilapia sparmanii, Clarias gariepinus and Micropterus salmoides, were associated with stations of Segment 1 on the $1^{\text {st }}$ ordination axis (Fig. 2). The remainder of the species were associated with stations of Segments 2 and 3 (Fig. 2).

There was no evidence of external disease and other anomalies, and all fish were considered to be in good health. Seven of the expected 10 species were collected in Segment 1. This seg-



Figure 3

Mean habitat diversity (a), proportional abundance of bass, M. salmoides, (b) and the relative FAll score (c) in each segment

ment, with a relative FAII score of $56.5 \%$, was rated as Class D (largely modified) (Table 4). Two alien species of fish, viz. Micropterus salmoides and Serranochromis robustus, were sampled in this segment. M. salmoides was collected at 4 out of the 5 stations sampled while $S$. robustus was collected at one sampling station. Habitat diversity was low $(<1.5)$, and the proportion of $M$. salmoides was highest (> 10\%) compared to the other segments (Fig. 3). Sixteen of the expected 20 species were collected in Segment 1 during the sampling period. The segment was classified as unmodified (Class A) with a relative score of $91.6 \%$ (Table 4). Species with a high intolerance rating, including Opsaridium zambezense, Chiloglanis neumanni and Zaireichthyes rotundiceps, were collected in this segment. Two exotics, M. salmoides and Oreochromis niloticus, were also collected. Oreochromis niloticus was collected at one sampling station only. Habitat diversity was high (mean habitat diversity index = 1.8), and the proportion of $M$. salmoides decreased (5.3\% of the total abundance) compared to Segment 1 (Fig. 3). Sixteen species, lower than the expected 26, were collected from Segment 3 . The segment, with a relative FAII score of $81.6 \%$, was classified as largely natural (Class B) (Table 4). Species with a high intolerance rating, collected in this segment were $O$. zambezense and C. neumanni. Micropterus salmoides and the river sardine, Mesobola brevianalis, were the two exotic species in this segment. Habitat diversity was highest (mean habitat diversity index = 2.06), and proportional abundance of $M$. salmoides was lowest (2.4\%) in this segment compared to the other segments (Fig. 3) 


\begin{tabular}{|c|c|c|c|c|c|}
\hline \multicolumn{6}{|c|}{$\begin{array}{l}\text { TABLE } 4 \\
\text { The FAll score based on the expected and observed fish species (indicated in } \\
\text { brackets) (after Kleynhans, 1999). The symbol * indicates that there was insuffi- } \\
\text { cient information available to estimate the frequency of occurrence. The symbol } \\
\text { e indicates exotic species and (p) indicates the segment in which it was present. }\end{array}$} \\
\hline \multirow[b]{2}{*}{ Species } & \multirow[b]{2}{*}{$\begin{array}{c}\text { Intolerance } \\
\text { rating }\end{array}$} & \multirow[b]{2}{*}{$\begin{array}{l}\text { Health rat- } \\
\text { ing }\end{array}$} & \multicolumn{3}{|c|}{ Frequency of Occurrence } \\
\hline & & & Segment 1 & Segment 2 & Segment 3 \\
\hline Mormyrus longirostris & 2.5 & 5 & & & $1(1)$ \\
\hline Cyphomyrus discorhynchus & 3.5 & 5 & & & $1(1)$ \\
\hline Marcusenius macrolepidotus & 2.5 & 5 & & $*(0)$ & $1(0)$ \\
\hline Petrocephalus catastoma & 3 & 5 & & & $*(0)$ \\
\hline Anguilla mossambica & 3 & 5 & & $*(0)$ & $*(0)$ \\
\hline A. bengalensis & 3 & 5 & & $*(0)$ & $*(0)$ \\
\hline Opsaridium zambezense & 4.5 & 5 & & $5(5)$ & $5(5)$ \\
\hline Barbus lineomaculatus & 2 & 5 & $5(3)$ & $5(3)$ & $1(0)$ \\
\hline B. unitaeniatus & 2.5 & 5 & & $3(3)$ & $5(5)$ \\
\hline B. radiatus & 2 & 5 & & $3(1)$ & $5(5)$ \\
\hline B. trimaculatus & 2 & 5 & $3(0)$ & $5(5)$ & $5(5)$ \\
\hline B. paludinosus & 2 & 5 & $5(3)$ & $5(1)$ & $3(0)$ \\
\hline Labeobarbus marequensis & 1.5 & 5 & $1(0)$ & $5(5)$ & $5(5)$ \\
\hline Labeo cylindricus & 3.5 & 5 & $1(0)$ & $5(5)$ & $5(5)$ \\
\hline L. molybdinus & 3.5 & 5 & & $*(0)$ & $1(0)$ \\
\hline Brycinus imberi & 3 & 5 & & & $5(5)$ \\
\hline Micralestes acutidens & 2 & 5 & & & $5(5)$ \\
\hline Hydrocynus vittatus & 4 & 5 & & & $*(0)$ \\
\hline Zaireichthys rotundiceps & 4.5 & 5 & & $5(5)$ & $3(0)$ \\
\hline Clarias gariepinus & 1 & 5 & $5(5)$ & $5(5)$ & $5(5)$ \\
\hline Chiloglanis neumanni & 5 & 5 & & $5(5)$ & $5(5)$ \\
\hline Pharyngochromis acuticeps & 1 & 5 & & $3(3)$ & $5(5)$ \\
\hline Pseudocrenilabrus philander & 1 & 5 & $1(1)$ & $3(3)$ & $5(5)$ \\
\hline Tilapia sparrmanii & 1 & 5 & $3(3)$ & $3(1)$ & $1(0)$ \\
\hline T. rendalli & 1 & 5 & $3(3)$ & $5(3)$ & $5(5)$ \\
\hline Oreochromis mossambicus & 1 & 5 & $1(1)$ & $3(3)$ & $5(5)$ \\
\hline Oreochromis niloticus $^{e}$ & & & & $\mathrm{p}$ & \\
\hline Serranochromis robustus ${ }^{e}$ & & & $\mathrm{p}$ & & \\
\hline Mesobola brevianalis ${ }^{e}$ & & & & & $\mathrm{p}$ \\
\hline Micropterus salmoides ${ }^{e}$ & & & $\mathrm{p}$ & $\mathrm{p}$ & $\mathrm{p}$ \\
\hline Species richness & & & $10(7)$ & $20(16)$ & $26(16)$ \\
\hline FAII score (expected) & & & 62 & 173.5 & 226 \\
\hline FAII score (observed) & & & 35 & 159 & 184.3 \\
\hline Relative FAII score (\%) & & & 56.5 & 91.6 & 81.5 \\
\hline Integrity class rating & & & $\mathrm{D}$ & $\mathrm{A}$ & $\mathrm{B}$ \\
\hline
\end{tabular}

\section{Discussion}

Segment 1, with 5 upstream stations, was rated as largely modified. The upstream segment under study, with a few farm dams that regulate flow, was dominated by sand and silt, and had low habitat diversity. Most of the small dams are stocked with bass, M. salmoides, which is an exotic predator that has become established on the upper section of the river system. Another exotic predator collected in Segment 1, Serranochromis robustus, was not well established in the catchment.

The impact of exotic species on indigenous species is well documented. For example the disappearance of Barbus treurensis from its type locality in the Treur River, Mpumalanga Province, South Africa, has been linked to the presence of exotic rainbow trout and small-mouth bass, Micropterus dolomieui
(Kleynhans, 1996). The decline in abundance and fragmentation of the distribution of galaxids, Galaxias olidus and G. vulgaris, in New Zealand and Australian rivers has been related to the presence of introduced piscivorous trout species (Closs and Lake, 1996; McDowall and Rowe, 1996). In Zimbabwe, Marshall and Gratwicke (2001) found that M. salmoides and S. robustus selectively preyed on the barbs (Barbus spp.) thereby reducing their diversity and abundance in the Upper Manyame catchment. Barbs are more conspicuous than other species because they are shiny, silvery fish that live in pools, and would therefore be vulnerable to diurnal sight predators (Marshall and Gratwicke, 2001). In this study, B. trimaculatus, was not collected in Segment 1 where it was expected to occur, while $B$. paludinosus and $B$. lineomaculatus were collected at 3 of the 5 stations where they were expected to occur. 
Of the 20 species expected in Segment 2, 16 were collected while the frequency of occurrence of the remaining 4 species could not be determined. These included species of marine origin such as the Anguilla species. The reasons why these species were not collected are not clear, and this may reflect that they are either scarce or would require an extended sampling period. The relative FAII class rating of A (unmodified) was, nevertheless, a reflection of less disturbed conditions, and was supported by the presence of species with high intolerance rating such as $O$. zambezense, C. neumanni and Z. rotundiceps. These species are habitat specialists and the loss of a preferred habitat is usually reflected by their absence. In the upper Manyame catchment, the distribution of these species has been limited due to fragmentation of the system by small dams, pollution and the impact of exotic predators (Gratwicke et al., 2003). Two exotic species, M. salmoides and Oreochromis niloticus, were collected in Segment 2 and both were not well established. Segment 2 was characterised by mostly rockier and fast-flowing habitats and deep pools. Most cyprinids, with elongated bodies that are favoured by the large-mouth bass, would avoid predation risk by living in aquatic habitats that are not preferred by bass such as riffles. Large-mouth bass do not prefer cichlids because of their rounded body form (Marshall and Gratwicke, 2001).

Kadye and Marshall (2007) noted that the construction of Kunzvi Dam near the Nyagui and Nora River confluence will regulate flow, and change the fish populations in this system. Changes both in the flooded area and downstream may allow cichlids, especially the exotic Oreochromis niloticus, to become more abundant than at present. O. niloticus has the potential to out-compete and displace indigenous cichlid species. It has been linked to the decline of $O$. variabilis and O. esculentus in Lake Victoria where it was introduced in the early 1950s (LoweMcConnell, 2000; Balirwa et al., 2003) while in Lake Kariba it was linked to the possible decline of O. mortimeri (Chifamba, 1998).

The class rating of Segment 3 as largely natural (B) was largely obscured by the fact that some species expected in this segment were not collected. These included species that were either rare or less frequent $(P$. catastoma, L. altivelis, $L$. congoro, L. molybdinus $H$. vittatus, $M$. macrolepidotus) or migratory (A. bengalensis, $A$. mossambica) and would otherwise need an extensive sampling period and other sampling techniques not used in this study. The impact of $M$. salmoides was unlikely since its proportional abundance was low and habitat diversity was high. Another exotic, the river sardine, Mesobola brevianalis, was also collected at one of the sampling stations. The river sardine was introduced into a lower Zambezi tributary, the Nyamombe River, which eventually flows into Mazowe in Mozambique (Bell-Cross and Minshull, 1988). It has evidently now moved upstream into the Mazowe system and may in future extend its range into the Nyagui. Although the impact of the river sardine could not be determined in the present study, competition with local species, especially small barbs, cannot be ruled out. Nevertheless, the presence of species with a high intolerance rating in Segment 3, such as $O$. zambezense and $C$. neumanni, was a reflection of a system that is less modified.

The results of this study suggest that the impact of bass was high when habitat diversity was low. Barbs, in particular, were the most affected since their distribution was lower that expected when the proportional abundance of bass was high. When habitat diversity, hence habitat complexity, is high, it is likely that there are more refugia which reduce the predation risk for vulnerable species. It can be concluded that the FAII's ecological principles, which define assemblage structure and func- tion in relation to present environmental conditions, provide an insight on the status of an assemblage in a given aquatic system, as was shown in this study. Nevertheless, challenges remain in the provision of a reliable reference condition that is the basis for comparison since it is based on historical data that may not be easily available for some systems. In cases where historical information on the distribution of fish species is available, recommendations have been made to come up with a hypothetical reference condition that usually is built on repeated sampling to produce a cumulative data set (Bozzetti and Schulz, 2004). It is recommended that more studies be carried out in Zimbabwe to assess the consistency of FAII results in determining the impact of introduced species on native species, and to assess the impact of other human activities, including pollution and siltation. Continuous sampling to assess the status of species of marine origin, especially the eels (Anguilla spp.) and gobies (Glossogobius spp.) that were previously recorded at high altitude in Zimbabwe, is important. The loss of these species may reflect other disturbances such as loss of connectivity with the ocean due to either dam building or siltation downstream.

\section{Acknowledgements}

The Government of Belgium through the University of Zimbabwe/Flemish Universities link funded this work. The assistance of Albert Chakona, Tendai Samukange, Taurai Bere and Cleopas Chinheya who helped with fieldwork is greatly acknowledged. Professor Brian Marshall (now with Lake Victoria Fisheries Organisation, Uganda) assisted with many aspects of this study and his efforts are greatly acknowledged.

\section{References}

BALIRWA JS, CHAPMAN CA, CHAPMAN LJ, COWX IJ, GEHEB K, KAUFMAN L, LOWE-McCONNELL RH, SEEHAUSEN O, WANINK JA, WELCOMME RL and WITTE F (2003) Biodiversity and fishery sustainability in Lake Victoria basin: an unexpected marriage. BioSci. 53 703-714.

BELL-CROSS G and MINSHULL JL (1988) The Fishes of Zimbabwe. National Museums and Monuments of Zimbabwe, Harare.

BELPAIRE C, SMOLDERS R, AUWEELE IV, ERCKEN D, BRIENE J, THUYNE G and OLLEVIER F (2000) An Index of Biotic Integrity characterizing fish populations and ecological quality of Flandrian water bodies. Hydrobiol. 434 17-33.

BILLIARD J, THOMAS RB and MONNIER D (1999) Fish communities and river alteration in the Seine Basin and nearby coastal stream. Hydrobiol. 400 155-166.

BOZZETTI M and SCHULZ UH (2004) An index of biotic integrity based on fish assemblages for subtropical stream in Southern Brazil. Hydrobiol. 529 133-144.

BRIENE J, SIMOENS I, GOETHALS P, QUATAERT P, ERCKEN D, LIEFFERINGE CV and BELPAIRE C (2004) A fish-based index of biotic integrity for upstream brooks in Flanders (Belgium). Hydrobiol. 522 133-148.

CHIFAMBA PC (1998) Status of Oreochromis niloticus in Lake Kariba, Zimbabwe, following its escape from fish farms. In: Cowx IG (ed.) Stocking and Introduction of Fish. Fishing News Books, Oxford.

CLOSS GP and LAKE PS (1996) Drought, differential mortality and the coexistence of a native and an introduced fish species in south east Australian intermittent stream. Environ. Biol. Fish. 47 17-26.

COLLARES-PEREIRA MJ and COWX IG (2004) The role of catchment scale environmental management in freshwater fish conservation. Fish. Manage. Ecol. 11 303-312.

DEPARTMENT OF WATER DEVELOPMENT (DWD) Zimbabwe National Water Authority and City of Harare (2002) Kunzvi-Harare Water Supply Project. Project Document.

GANASAN V and HUGHES RM (1998) Application of and index of biotic integrity (IBI) to fish assemblages of the rivers Khan and 
Kshipra (Madhya Pradesh), India. Freshwater Biol. 40 367-383.

GORMAN OT and KARR JR (1978) Habitat structure and stream fish communities. Ecol. 59 507-515.

GRATWICKE B and MARSHALL BE (2001) The relationship between the exotic predators Micropterus salmoides and Serranochromis robustus and native stream fishes in Zimbabwe. J. Fish. Biol. 58 68-75.

GRATWICKE B, MARSHALL BE and NHIWATIWA T (2003) The distribution and relative abundance of stream fishes in the upper Manyame River, Zimbabwe, in relation to land use, pollution and exotic predators. Afr. J. Aquat. Sci. 28 25-34.

HOCUTT CH, JOHNSON CH, HAY C and ZYL BJ (1994) Biological basis of water quality assessment: the Kavango River, Namibia. Rev. d'Hydrobiol. Trop. 27 361-384.

HUGUENY B, CAMARA S, SAMOURA B and MAGASSOUBA M (1996) Applying an index of biotic integrity based on fish assemblages in a West African river. Hydrobiol. 331 71-78.

JOY MK and DEATH RG (2004) Application of the Index of Biotic Integrity Methodology to New Zealand Freshwater fish communities. Environ. Manage. 34 415-428.

KADYE WT and MARSHALL BE (2007) Habitat diversity and fish assemblages in an African river basin (Nyagui River, Zimbabwe). Afr. J. Ecol. 45 374-381.

KARR JR (1981) Assessment of biotic integrity using fish communities. Fisheries 6 21-27.

KLEYNHANS CJ (1996) Threatened fishes of the world: Barbus treurensis Groenewald, 1958 (Cyprinidae). Environ. Biol. Fish. 45282.

KLEYNHANS CJ (1999) The development of a fish index to assess the biological integrity of South African rivers. Water SA 25 265-278.

LOWE-McCONNELL RH (2000) The role of Tilapias in Ecosystems. In: Beveridge MCM and McAndrew BJ (eds.) Tilapias: Biology and Exploitation. Kluwer Academic Publishers, Dordrecht.
MARSHALL BE and GRATWICKE B (1999) The barred minnows (Teleostei: Cyprinidae) of Zimbabwe: is there cause for concern? S. Afr. J. Aquat. Sci. 24 157-161.

McDOWALL RM and ROWE DK (1996) Threatened fishes of the world: Galaxias gracilis McDowall 1967 (Galaxiidae). Environ. Biol. Fish. 46280.

MINSHULL JL (1993) How do we conserve the fishes of Zimbabwe? Zimb. Sci. News 27 90-94.

OBERDORFF T, PONT D, HUGUENY B and CHESSEL D (2001) A probabilistic model characterising fish assemblages of French rivers: a framework for environmental assessment. Freshwater Biol. 46 399-415.

OSBORNE LL, KOHLER SL, BAILEY PB, DAY DM, BERTRAND WA, WILEY MJ and SAUER R (1992) Influence of stream location in a drainage network on the index of biotic integrity. Trans. Am. Fish. Soc. 121 635-643.

SCHLOSSER IJ (1982) Fish community structure and function along to habitat gradients in a headwater stream. Ecol. Monogr. 52 395-414.

SKELTON PH (1990) The conservation and status of threatened fishes in southern Africa. J. Fish. Biol. 37 87-95.

SKELTON PH (2001) A Complete Guide to the Freshwater Fishes of Southern Africa $\left(2^{\text {nd }}\right.$ edn.). Struik, Cape Town, South Africa.

TER BRAAK CJF and SMILAUER P (1998) CANOCO Reference Manual and User's Guide to CANOCO for Windows: Software for Canonical Community Ordination (Version 4). Microcomputer Power, Ithaca, New York.

TOHAM AK and TEUGLES GG (1999) First data on an index of biotic integrity (IBI) based on fish assemblages for the assessment of the impact of deforestation in a tropical West African river system. Hydrobiol. 397 29-38. 
Available on website http://www.wrc.org.za ISSN 0378-4738 = Water SA Vol. 34 No. 1 January 2008

ISSN 1816-7950 = Water SA (on-line) 